\title{
Review on the Implementation of Physical Education Learning
}

\author{
Syafruddin*, Uswatul Hasanah \\ Physical Education \\ Faculty of Sport Science \\ University of Padang
}

\begin{abstract}
The purpose of this study is to find out learning planning, implementation of learning, and evaluation of learning for sports and health physical education lessons. This type of research is descriptive, involving 371 students from vocational high schools. The instruments used for data collection are questionnaires. The data analysis used the frequency distribution formula. The results of data analysis obtained the results of the study as follows: 1) planning physical education learning on the implementation of physical education learning is 66.32 with sufficient qualifications, 2) the implementation of learning to the implementation of physical education learning is $\mathbf{6 7 . 9 5}$ with sufficient qualifications, 3 ) evaluation of learning to the implementation of learning physical education is $\mathbf{5 3 . 5 3}$ with fewer qualifications.
\end{abstract}

Keywords - Physical education, learning, students

\section{INTRODUCTION}

Article 18 paragraphs 1 and 2 of Law Number 3 of 2005 concerning the National Sports system, that "Sports education is held as part of the educational process and is carried out both in formal and non-formal education channels through intracuricular or extracurricular activities"

Furthermore"Given the importance of sports activities to improve physical fitness, it is necessary to empower sports as early as possible both at school and to the wider community"[1]. "Physical education is a process of education through physical activity, game or sport that is chosen to achieve educational goals" [2]. Meanwhile, "physical education is an educational process to actualize human potential in the form of attitudes, actions, and works by its form, content, and directions to the roundness of human personality with the ideals of humanity" [3]. Similar opinion was also expressed by" physical education is a process of interaction between the learners with the environment, through physical activity systematically managed to reach Indonesia seutuhnya" [4]. Next, "Education physical is a learning process that is designed to improve physical fitness" [4].

Of the various terms above can be concluded that physical education is a process of learning through physical activity to stimulate the growth and development of affective, cognitive and psychomotor overall, harmonious, balanced toward complete Indonesian man. Physical education is also part of the overall education are inseparable and contribute to the realization of general education. Then it should be understood that the physical education will also occur the learning process.

Mulyasa says: "lesson plan (RPP) is a plan that describes procedures and learning management to achieve one or more of the basic competencies specified in the national curriculum and is described in the syllabus" [5].. RPP is an important kompenen of kurukulum level education units (SBC) that development should be carried out secra professional.

In penjasorkes learning teacher must have a plan set forth in the form of RPP, RPP which is the elaboration of a curriculum that is used as guidelines in the establishment of competence of learners. In the learning process penjasorkes on ummnya do dioutdor or outside the classroom. "The situation outside the classroom aims so that learners can have a broad space and can bermaian freely because anak penjasorkes learning required to play, it certainly requires careful planning of educators, especially teachers penjasorkes" [6].

The main purpose of evaluation in the process pembelajran is "to obtain accurate data tentan level student achievement of learning objectives that can be pursued follow-up". Then the benefits of teacher evaluation is: "a) the teacher can know testee-testee already entitled melanjutakan lesson or testee who have successfully mastered the lesson material. With the guidance of teachers can be more focused to the testee unsuccessful. b) teachers will determine whether a given material is appropriate for testee or not, so as to provide pembelajran the next time he will be using the subject matter is appropriate for the testee while yet dpat made efforts to repair properly. c) the teacher will know aapakah method of evaluation tools that will be used is right or not. If most of the testee who scored poorly on evaluations conducted, then it is likely to be caused by a lack of proper methods or evaluation tools are not appropriate. "

Based on the observation that researchers do in SMK 1 Linggo Sari Baganti South Coastal District, which is one form of the review of the implementation of learning penjasorkes. Many students do not listen to the teacher's explanation in the implementation process of learning Penjasorkes, students' interest towards learning less because there's nothing interesting dipembelajaran conducted and no encouragement from teachers penjasorkes itself, the location of the school tight close to the hustle of being on the edge of 
the highway that many disturbing noise and students have the opportunity to play outside of school perkarangan, here the support of the school principal is also required because that oversees and is responsible for the school. The aim of the study is to examine the learning plan,

\section{RESEARCH METHODS}

Based on the issues raised, this study classified the descriptive study aimed to describe the state of the data as it is. The research was conducted at SMK Negeri 1 Linggo Sari Baganti South Coastal District. While the study period, lasts from December 2017 until January 2018. In this study are all students of SMK Negeri 1 Baganti Linggo Sari, numbering as many as 371 students. With details of class $\mathrm{X}$ as many as 138 people. The sample in this study were taken by using simple random samplin. So the sample in this study is 50 students. Instrument in this research is to give a questionnaire to students. The analysis technique used is descriptive analysis technique as a percentage.

\section{RESEARCH RESULT}

\section{Lesson Planning Indicators Penjasorkes}

Steps taken to find a picture on the Role of Penjasorkes learning is to calculate the raw scores of questions given to students, then the score is converted into a percentage value using the formula. After that, student scores are grouped based on the assessment indicators that have been defined. Furthermore, the value is inserted into the table on learning Planning penjasorkes. The data analysis Penjasorkes teacher role students who answered yes to the indicator 1adalah 465jawaban with the percentage 23.25 while answering Not 1535 jawaban with the percentage $76.75 \%$, average score of students' views of the indicator 1 is 9.30 , The results of the data analysislearning penjasorkes (Indicator 1) can be seen in the following table.

Table 1. Planning learning penjasorkes

\begin{tabular}{|c|c|c|}
\hline answer & Frequency & Percentage \\
\hline Yes & 465 & $23.25 \%$ \\
\hline No & 1535 & $76.75 \%$ \\
\hline amount & $\mathbf{2 0 0 0}$ & $\mathbf{1 0 0 \%}$ \\
\hline
\end{tabular}

\section{Learning Implementation indicator Penjasorkes}

Steps taken to find a picture of the lesson Penjasorkes is to calculate the raw scores of questions given to students, then the score is converted into a percentage value using the formula. After that, student scores are grouped based on the assessment indicators that have been defined. Furthermore, the value is inserted into the table on the Implementation of Learning Penjasorkes. The data analysis lesson Penjasorkes who answered yes to the second indicator is 445 answers with a percentage $22.25 \%$ while who answered No 1555 jawaban with a percentage of $77.75 \%$, average scores of students visits of the indicator 2 is 8.9. Results of analysis Learning Implementation Penjasorkes (indicator 2)can be seen in the following table.

Table 2. Learning Implementation Penjasorkes

\begin{tabular}{|c|c|c|}
\hline answer & Frequency & percentage \\
\hline Yes & 445 & $22.25 \%$ \\
\hline No & 1555 & $77.75 \%$ \\
\hline amount & $\mathbf{2 0 0 0}$ & $\mathbf{1 0 0 \%}$ \\
\hline
\end{tabular}

3. Indicators Evaluation of learning penjasorkes

Steps taken to find out the description of the learning evaluation penjasorkes is by calculating a raw score of questions given to students, then the score is converted into a percentage value using the formula. After that, student scores are grouped based on the assessment indicators that have been defined. Furthermore, the value is inserted into the table of the evaluation. Learning evaluation data analysis, students answer Yes to the indicator 3 are 348 answers with a percentage of $17.40 \%$, while that answered No 1652 answers with a percentage of $82.60 \%$, average scores of students seen from the indicators 3 adalah6,96. The results of the data analysis Evaluation of learning penjasorkes (indicator 3) can be seen in the following table.

Learning Evaluation Table Penjasorkes

\begin{tabular}{|c|c|c|}
\hline answer & Frequency & Percentage \\
\hline Yes & 348 & $17.40 \%$ \\
\hline No & 1652 & $82.60 \%$ \\
\hline amount & $\mathbf{2 0 0 0}$ & $\mathbf{1 0 0 \%}$ \\
\hline
\end{tabular}

\section{DISCUSSION}

\section{Lesson Planning Penjasorkes}

Lesson plan is essentially a short-term planning for estimating or projecting what will be done in learning. This means that teachers prior notice make or prepare an implementation plan learning (RPP) before being implemented pembeljaran process, as well as physical education teachers in the subjects of sports physical education and health at SMK Negeri 1 Linggo Sari Baganti South Coastal District.

Studiying implementation plan is a minimum of three activities, namely idetenfikasi needs, formulation of basic competence, and preparation of the program of learning. Identifying needs among other objectives to involve motivating learners to learning experienced by learners. Basic competence merupkan something to being owned by the learner, and is a major kompoonen must be formulated teachers in learning, which has an important role to determine the direction pemebeljaran. While programming gives directions to a program that distinguishes it from other programs.

Based on data analysis and findings for variable peneliitianpembeljaran planning penjasorkes obtained by $66.32 \%$ level of achievement in the category enough. It can dikatan that penjasorkes teacher at SMK Negeri 1 Linggo 
Sari Baganti, please understand penjasorkespembeljaran planning functions.

Studiying planning is "an application of rational, systematic analysis perkembanagan process of education with the aim of education is more effective and efficient in accordance with the needs and goals of learners". Thus when associated penjasorkes important learning plan prepared by physical education teachers in order to meet the learning penjasorkskebuutuhan learners in accordance with the purpose.Besides teaching learners penjasorkes given more effective and efficient in achieving the objectives of the penjasorkespembelajran.

\section{Learning Implementation Penjasorkes}

In accordance with the analysis of the data and research analysis on the implementation of learning penjasorkes in SMK 1 Linggo Sari Baganti South Coastal District of the obtained level of achievement of $67.95 \%$ in the category enough. This means penjasorkes teacher at SMK Negeri 1 Linggo Sari Baganti is already implementing learning quite well. In SBC penegembanganpenjasorkes subjects, exercising their learning should pay attention and karakterristik learners against a given standard materials teachers kajian.Artinya material not only serves as transpormator, but should serve as a motivator to evoke the spirit of learning, and to encourage students to learn to use berbagia variety of media, and appropriate learning resources.

Mulyasa revealed "that in general the implementation of learning includes three activities, namely: the opening, the establishment of competence and cover". This means that a professional teacher should be able to implement the learning process with three sets of opening, that is how the teacher opened a pemeblajaran. Then "the formation of competence, it is important to be do it teachers to support the establishment of competence in self-learners, and each end of the learning process mentupGuupembelajran well" [7].

Furthermore explains that "good planning is to help the implementation of pembeljaran, karanabaiak teachers and learners know for certain objectives to be achieved and how to achieve it, so the teacher can maintain the situation so that students can focus on learning programmed " [7]

\section{Evaluation of Learning Penjasorkes}

Feedback in the process of physical education and sports are thriving student health and civilized berbudya fit for purpose. Physical education is the interaction with the environment anatara learners, through physical activity systematically managed to get a complete Indonesian.

To determine the transformation efficiency and effectiveness in the learning process pendidijkan physical exercise and health need to be implemented evaluation. Penjasorkes important in learning because seen as a process evaluation to determine the success of learners in the learning process.According to renowned experts in the evaluation that Stufflebeam in Arikuntosays that "evaluation is pengambaran process, search, and highly useful information for decision making in determining alternative decisions" [7]

Thus the explanation above, when related to teacher evaluation process penjasorkes, then it is very important for teacherspenjasorkes to determine the decision of the picture of student success in achieving learning goals. Surely penjasorkes teachers in evaluating or assessing student learning outcomes in learning penjasorkes accordance with the judging of student learning outcomes obtained.

Based on the results of the evaluation of data penjasorkes learning in SMK 1 Linggo Sari Baganti South Coastal District, obtained the level of achievement of $53.53 \%$ and are at less category. This means penjasorkes teacher evaluation has not yet implemented properly, because the classification of students in the low category.

Benchmarkingisa standard for measuring the performance of the running, the process and results to achieve a satisfactory advantage. Judging program conducted by dapertemennasioanl education and continuous service and continuous education. Judging program was conducted to determine the suitability of the curriculum with the basic functions and tujjuan national education, as well as compliance with the demands of the development of society and memajuan times.

\section{CONCLUSION}

Based on the results of research that has been described in the previous chapter, it can be concluded as follows:

1. Variable penjasorkes learning plan obtained by the level of achievement of $66.32 \%$ in the category enough. Thus it can be interpreted penjasorkes teachers already doing quite well pembelajran planning.

2. Variable penjasorkes implementation of learning gained by $67.95 \%$ level of achievement in the category enough. Thus it can be interpreted penjasorkes teachers already doing quite well pembelajran planning.

3. Variable penjasorkes learning evaluation obtained by $53.53 \%$ level of achievement in the category enough. Thus it can be interpreted penjasorkes teachers already implementing pembelajran poor planning.

\section{REFERENCES}

[1] Z. Zulbahri, "Tingkat Kemampuan Daya Tahan Jantung dan Pernafasan Mahasiswa Pendidikan Olahraga dan Kesehatan Universitas Pasir Pengaraian", Gelanggang Olahraga: Jurnal Pendidikan Jasmani dan Olahraga, vol. 3, no. 1, pp. 96-101, Oct. 2019.

[2] Husdarta. "ManajemenPendidikanJasmani”.Bandung :Alfabeta, 2011, pp. $45-46$

[3] Sukintaka. "Teori Pendidikan Jasmani”. Yogyakarta : Esa Grafika Solo, 2001, pp. 34-35 
[4] A. Suryobroto. "Diktat Kuliah Persiapan Profesi Guru PendidikanJasmani”, Yogyakarta: FIK-UNY. 2005. pp, 28-29

[5] Mulyasa. "Manajemen Kepemimpinan Kepala Sekolah". Jakarta: Bumi Aksara, 2012. pp. 35-36.

[6] Arikunto. "ManajemenPenelitian". Jakarta: Bumi Aksara, 2004. Pp. 32-33. 